\title{
WOMEN WRITING THE AMERICAS: LITERATURE, ECOLOGY, AND DECOLONIZATION
}

\author{
MULHERES ESCREVENDO AS TERRAS AMERICANAS: LITERATURA, ECOLOGIA E DESCOLONIZACÃO
}

\begin{abstract}
This essay analyzes how multiethnic women writers of the Americas draw a map of a critical geography by delineating the interrelated brutalization of human beings and the environment at the colonial-decolonial interface. Its theoretical approach is comparative, interdisciplinary, and intersectional and embedded in Cultural/ PostColonial Studies and Ecocriticism with the objective to problematize the issue of identity, ethnicity, and gender in correlation with the land qua place and style of life within a capitalist system. The objective is to reveal and examine the decolonial attitude in texts by multiethnic women writers of the Americas: what is decolonization and how is it translated into the narrative structure, style and theme?
\end{abstract}

Keywords: Multiethnic Women Writers of the Americas. Ecology. Colonization/ Decolonization.

\section{RESUMO}

O trabalho analisa como escritoras multiétnicas das Américas desenham um mapa de uma geografia crítica ao delinear a inter-relacionada brutalização dos seres humanos e do (meio) ambiente na interface colonização/ descolonização. Baseado numa abordagem teórica comparativa, interdisciplinar e interseccional, embutida nos Estudos Culturais/ Pós-Coloniais e na Ecocrítica, o ensaio problematiza a questão da identidade, etnicidade e gênero em relação à terra enquanto lugar e estilo de vida dentro do sistema capitalista. O objetivo é revelar e examinar a atitude decolonial na escrita de autoria feminina multiétnica das Américas: o que é e como se traduz a descolonização na estrutura, estilo e tema da narrativa?

Palavras-chave: Literatura de Autoria Feminina/Multiétnica das Américas. Ecologia. Colonização/ Descolonização.

(...) the land must be returned to the people whose ancestors had lived on the land for twenty thousand years continuously. (Leslie Marmon Silko)

(...) the land is our mother, the rivers our blood. (Mary Crow Dog)

Roland Walter

Universidade Federal de Pernambuco. Email:walter_roland@hotmail.com; rolandgwalter@yahoo.com 
The earth, like the sky and water, had no owner until the foreigners, using the forced labor of the Arawaks, took control of it in order to cultivate never-before-seen plants. It was in that time that the custom of killing people with dogs was begun. (Isabel Allende)

Across the Americas, different forms and practices of physical, epistemic, and ecological violence constitute a systemic network generated by and based upon an ongoing colonialidad del poder (Quijano). In the process, epistemic violence naturalizes material violence imposed upon all biotic species. Bodies, minds, lands, seas and natural resources become neocolonial contact zones where ideological disguise and the opacity surrounding the intricate relationship between national institutions and supranational financial operations permit the establishment of diffuse networks of power who control and profit from the flows of corporate capital. It is needless to say that in many parts of the Americas (and the world) this market-driven relationship between the local and the global is based on the systematic negation of human rights and responsible land tenure as stipulated in various international agreement ${ }^{2}$, and exacerbates existing inequalities between and within city sections, regions and nations. Thus, in the Americas, situated somewhere between the Middle Ages and Modernity, contemporary relations of power orchestrate the marginalization, animalization, and demonization of diverse others to the syncopated rhythms of violent (trans)national deterritorializations and reterritorializations resulting in more precarious job opportunities, less education, health service, and humane living conditions. In this contemporary global panorama of "geopolitical chaos" (Ramonet, 2002)3, which according to Samir Amin is characterized by the subordination of "every aspect of social life to the imperatives of economic rationality" (2000: 136), the Americas, according to Francisco Alarcón (1992: 34), continue to be "invaded, occupied, whitewashed, gagged, suppressed, sanitized and at best, ignored." In other words, colonial violence has developed through manifold stages into neocolonial violence with First Nation peoples, Black people, women, and gypsies, to name just a few, being constantly demonized, subalternized, invented and killed through a naturalized imposition of Western norms and codes that function as markers of civilization. In the process, their bodies become the main target and map of (neo) colonial violence. Through torture, rape, and mutilation, Western norms, codes, and symbols were literally burnt and beaten into their bodies. This corporeal violence

1 In sum, Anibal Quijano focuses on the hierarchical categorization of the world's regions and populations through Western hegemony: the intersectionality of race, ethnicity, sex, gender, class, age within an exploitative work system based on extractive policies determined by (inter)national relations of power and monetary fluxes. In her essay "Colonialidad y genero" (2008), María Lugones supplements Quijano's analysis by focusing on gender - a social category, she argues, Quijano mentions but does not thoroughly take into consideration.

2 Inter alia, the Universal Declaration of Human Rights, the United Nations Declaration on the Rights of Indigenous Peoples; the OAS American Declaration on the Rights of Indigenous Peoples; the InterAmerican Commission on Human Rights; the Inter-American Court of Human Rights; the InterAmerican Commission of Women.

3 Translations in this essay are mine. 
was and continues to be accompanied and justified by a (neo)colonial discourse construing the dehumanized, animalized Other on the basis of ethnic, racial, gendered, and/or classist origin. In neoliberal times of globalization, we might add immigrants and refugees as abject Others produced by man-made ecological disasters and the systematic development of underdevelopment. This imposed mobility, itself originating in violence, translates into more violence, marginalization, and vulnerability in the host countries through the denial of such basic human rights as education and health service, police brutality, few and underpaid jobs, and heightened incarceration, among others.

Whereas the body is the prime target of diverse forms and practices of violence, the mind contributes to the festering of the (neo)colonial wounds by internalizing the value system of the hegemonic discourse. In Black Skin, White Masks, Frantz Fanon writes about the complex negotiation of identity in a colonial context: "The colonized is elevated above the jungle status in proportion to his adoption of the mother country's cultural standards (1967: 18)." In An Other Tongue: Nation and Ethnicity in the Linguistic Borderlands, Alfred Arteaga refers to this process of schizophrenic self-denigration as "autocolonialism." It occurs when "the autocolonist effaces or denigrates him/herself from within. In the endeavor to mimic the monologue of power, the Other harmonizes with it and suppresses difference" (1994: 17). Through the internalization of the hegemonic, hierarchical value system based on domination, exploitation, and self-hatred — "a zone of nonbeing" (Fanon, 1967: 8) — this "existential deviation" (Fanon, 1967: 14) results in psychological strain, anger and violence as well as shame and guilt with regard to one's own culture and self, or, as Eliane Potiguara writes: "shame is the result of the stigma" (2019: 29).

In (neo)colonial contexts, this physical and epistemic violence is very often accompanied by ecological violence: land grabbing, deforestation, mining, pesticides, monoculture of crops, agribusiness, industrial sites, garbage dumps, infrastructure (railroads, freeways, etc.) for the maximization of profit. What has climaxed in the contemporary man-made destruction of the Brazilian Cerrado and Amazon rainforest, for example, has been going on for centuries throughout the Americas. Antonio Benítez-Rojo reminds us that in Cuba (neo)colonization and its diverse machines - "the Taino Machine," the Iberian Machine," the Creole Machine," "the Republican Machine," the Socialist Machine," and "the Transition Machine" has had a devastating impact on the island's flora and fauna. From pre-Columbian deforestation, colonial desertification and contamination of the rivers based on "the demolishing stride of the sugar mill" (2005: 40) to the contemporary tourism industry and population growth, Cuba has experienced an "ecological catastrophe" (2005: 43).

Thus, land is one of the principal key issues of the colonialidad del poder that imbues the interface of (neo)colonialism and decolonization. The (neo)colonial burning and looting of las tierras americanas has rendered many hemispheric Americans homeless and accounts for their brutalization: homeless, angry orphans on the run born in and spreading violence. In Toni Morrison's A Mercy (2008: 150), the narrator observes that the process of colonization in the United States caused 
the fragmentation and alienation of people and things. One of the most insidious effects of the plantation system, enslavement of Africans and genocide of indigenous peoples was, according to Morrison, that all those involved as well as the following generations, became "orphans" characterized by a "withering inside that enslaves and opens the door for what is wild" (2008: 160). In Beloved, Stamp Paid's thoughts reveal this disavowed wild(er)ness of colonial orphanhood as follows: "[i]t was the jungle whitefolks planted in them [blacks]. And it grew. It spread. (...) until it invaded the whites who had made it. Touched them everyone. Changed and altered them. Made them bloody, silly, worse than even they wanted to be, so scared were they of the jungle they had made. The screaming baboon lived under their own white skin" (1989: 244). In Metade Cara, Metade Máscara, Eliane Potiguara (2019: 37) points to alcoholism as one of the roots of indigenous orphanhood when she describes a baby who stops her "bursts of laughter (...)/ With a flavor of alcohol (...)/ She is a hungry child/ Sick/ Orphaned of parents/ Orphaned of a country." These roots appear to be rhizomic offshoots of an ongoing colonization, as Potiguara (2019: 44) notes: "The demarcation of indigenous land was never a governmental priority. A policy that guaranteed and respected indigenous tribes as distinct sociopolitical and cultural unities should be a priority qua historical respect." She adds that the interests and cultural specificities of Brazil's First Nations where never taken into consideration by the government. Finally, the narrative voice in Jamaica Kincaid's A Small Place denounces the orphanhood of the world's post-colonial people, "the millions of people (...) made orphans: no motherland, no fatherland, no gods, no mounds of earth for holy ground (...) and worst and more painful of all, no tongue. For isn't it odd that the only language I have in which to speak of this crime is the language of the criminal who committed the crime?" (1989:31)

The messy, tangled network of diverse types of domination and resistance that constitutes the make-up of this (neo)colonial orphanhood growing and spreading from the plantation system of the past to the ghettos and shanty towns of the present is responsible for the homelessness in which many characters dwell in works by inter-American women writers; a dwelling in homeless displacement. ${ }^{4}$ In Paradise, Morrison's double writing, a transwriting of double-consciousness into double vision, emphasizes her view of a world qua "real earthly home"; a decolonized world where land is not sold, robbed or unlawfully possessed, but composed of homeplaces where mutual respect governs a balanced relationship between the species - a place that existed, according to the narrator, in the past, before "the whole of Western history, (...) the beginning of organized knowledge, (...) pyramids and poison bows, (...) when

\footnotetext{
4 In "The Bear," William Faulkner has memorably described the cause of this displacement and inherent brutalization as the "curse of the land," "that whole edifice intricate and complex and founded upon injustice and erected by ruthless rapacity" (1977: 291) transforming "wilderness" into "tamed land" (1977: 252). In Siete ensayos de interpretación de la realidade peruana, José Carlos Mariátegui argues that the "indigenous issue" has its roots in "the regime of land ownership" (2009: 153). In general, neoliberal policies combined with debt crises throughout much of Latin America have strengthened large landholding systems and furthered expropriation of land for export culture, mining, logging, and tourism, among others.
} 
rain was new, before plants forgot they could sing and birds thought they were fish" (1998a: 213). In this sense, Morrison's “deracing of the world” (1998b: 11) is a "concrete utopia" (Bloch, 1985: 131-132) of an existence without race, gender, class, property, and biological species functioning as principles of a hierarchical social organization and promoting differential patterns of the rights and duties of citizenship.

"Deracing of the world," then, means first and foremost respecting difference and establishing harmonious relationships based on justice and love so as to mend the broken balance between the human and the nonhuman species. It is in Tar Baby, her fourth novel, that Morrison most impressively delineates a fissured world where plants, trees and animals lament the destructive behavior of human beings; that is, nature is seen through its specific elements rather than as a holistic frame for the characters' actions. Set on a fictitious Caribbean island, the novel juxtaposes the white owners of a winter house and their black servants in contrary complementarity, undermining the clear-cut divisions between the pairs and their roles and thus staging in carnivalesque fashion a neocolonial version of plantation life in the 1980s. Nature, while being ravaged by the dictates of modern capitalism, remembers the past, joining forces with the maroon horsemen who have lived in the woods since their escape from slavery centuries ago. Whether in the scene of the butterflies criticizing Jadine's fetishistic reification - she loves to lie down and relax on "the hides of ninety baby seals stitched together" (1983: 74) —, or the swamp womens' astonishment at Jadine's rejection of her blackness, specifically the role of black women in her rural community (1983: 157), nature feels, thinks and acts in its own right and is read in symbolic terms to denounce a materialist-imperialist social structure that causes not only Jadine's ethnocultural alienation and fragmentation, but an ecological disaster that since the plantation system to our present times of global tourism/cosmopolitanism has caused terrible havoc. Under the impact of neocolonial imperialism - rich white tycoons building their vacation homes - the island's flora and fauna express and act in the face of their destruction:

(...) clouds and fishes were convinced that the world was over, that the sea-green green of the sea and the sky-blue sky of the sky were no longer permanent. Wild parrots (...) agreed and raised havoc as they flew away to look for yet another refuge. (...) The clouds gathered together, stood still and watched the river scuttle around the forest floor, crash headlong into the haunches of hills with no notion of where it was going (...). The clouds looked at each other, then broke apart in confusion. (...) When it was over, and houses instead grew in the hills, those trees that had been spared dreamed of their comrades (...). Then the rain changed and was no longer equal (1983: 7-8). 
Morrison attributes the power of creation to the elements of nature, which become agents with voices and thoughts rather than victimized objects. Furthermore, the mythomagical maroon horsemen who since having fled the plantation roam the island's hills and rain forest, seeing "with the eye of the mind" (1983: 131), contribute to an intercultural ethos and worldview based on a time-space continuum in which all human and nonhuman beings, alive or dead, are connected: a cosmology where African and American elements of culture meet and act in a transcultural contact zone. In order to transmit this dynamic relationship between the world of spirits, humans, animals, plants and trees within a temporal flow between the past, present, and future, Morrison delineates a landscape that acts through the mediation of human perception. It is important to highlight that this mediation is rooted in a perception of the natural order of the universe in which communication and knowledge are not only human attributes, but characteristics which pertain to nonhumans too. If, following Morrison (1990: 210) "a void may be empty, but is not a vacuum," I contend that she fills the voids of Western discourse with African spirituality and thereby supplements linear and hierarchical relationships based on separation with circular detours, that is, dynamic relationships between humans and nonhumans, times and space, re-creating the universe as an interconnected organism characterized by a dynamic coexistence of all forms of life. Morrison's roots in African spirituality reside precisely in her use of spirit as vital force and cosmic energy whose fluxes connect spheres of visible and invisible existence. If, as Nada Elia (2001: 151) has stated, "Africana women novelists are mediators (...) functioning liminally," then Morrison, located on the interlocking hyphen between African-American, linking and separating two continents and two cultural epistemes, is a transcultural mediator of the tension-laden bonds that hold the two in relationship.

What Morrison mediates transculturally in her entire oeuvre is knowledge. Knowledge is situated, that is, it is locally specific even if what we know and how we enact this knowledge in our daily affairs is influenced by global affairs and social media. Chickasaw poet, novelist and essayist Linda Hogan, in her seminal essay "First People," emphasizes the importance of "systems of knowledge and thought": "Systems of thought create our perception and influence every aspect of how the world is experienced by members of a race or culture. We are educated into our ways of thinking and perceiving, our spiritual and mental orientations" (1998: 11). Furthermore, she states that the Western system of knowledge "has resulted in a way of living in the world that has broken the trust between human and animal" and "has taken us to a point of devastating loss" (1998: 11). Therefore, she urges us "to rethink not only the stories of a culture but where these stories take their people, and to what ends" (1998: 11). The stories of tribal cultures, Hogan argues, are imbued with a system of belief and knowledge that reflects "an ancient understanding (...) of our shared lives on Earth. (...) insights that came from (...) intellectual traditions and ways of living that were tried, tested, and found true over many thousands of years and on all continents" (1998: 10-11). Stories, then, are much more than thoughts expressed in words and phrases. As constituent parts of ceremonies and rituals, stories "tell 
us (...) how to keep the world alive" and "how to put ourselves back together again. In the language of ceremony, a person is placed - bodily, socially, geographically, spiritually, and cosmologically - in the natural world extending all the way out into the universe. This placing includes the calling in of the animal presence from all directions" (1998: 14). Western thought and knowledge has systematically destroyed and vilified this "ancient way of being" (1998: 15) in the name of civilization, progress and capitalistic accumulation of profit (1998: 17). "Through our failed humanity," Hogan alerts, we are not only losing what nourishes us, but ourselves, our "human traits of love, empathy, and compassion. (...) what brings us to love and human fullness" (1998: 15).

In her creative and critical texts, Hogan strives to break down the culture/ nature dichotomy and heal the alienation between the human and nonhuman worlds. Echoing Chief Joseph's memorable statement made in early May 1877, at the last council between the Nez Perce Indians and representatives of the United States government before the outbreak of the Nez Perce War — "The earth and myself are of one mind. The measure of the land and the measure of our bodies are the same" (1971: 54) - Hogan has stated that "[w]e are all the same world inside different skins, and with different intelligences" (1998: xiv). Thus, for Hogan there is no difference between the ongoing genocide of Native American peoples and the ongoing destruction of nature: "what happens to people and what happens to the land is the same thing" (1995: 89). The explicit sense of this deep link between matter and mind, land and body, expressed by Chief Joseph and Linda Hogan, is that mind is not the special province of human beings. The specific landscape from which a tribe emerges determines their ethos and worldview, providing tribal societies with the founding cultural categories and symbols, the classificatory schemes of sameness and difference, the mythopoetic processes of original naming and informing the language to articulate the underlying order of things and knowledge through which they interpret reality. Therefore, removal from this landscape initiates an alienation not only from many aspects of a tribal way of life, but also from the self as part of the tribe located within the landscape. 5 This explains that the ongoing experience of invasion, genocide, dispossession, colonization, relocation and ethnocide - the darker, bloody side of the American Dream - has disrupted the notion of home/ identity within First Nation cultures. This is also why so many characters in Native American fiction, do not feel at home both in their tribal culture, whose language they do not speak, and in the world of white culture where they occupy the outer margin, hovering as the invisible shadow over the colonizer's guilt-ridden racialized memory. ${ }^{6}$ Thus, as Louis Owens (1992: 5) argues, "[t]he recovering or rearticulation

5 For an essayistic delineation of this topic, see Leslie Marmon Silko's Yellow Woman and a Beauty of the Spirit (1996). In Silko's novel Ceremony (1977: 45), Josiah expresses this interbiotic identitarian relationship as follows: "He pointed his chin at the springs and around at the narrow canyon. 'This is where we come from, see. This sand, this stone, these trees, the vines, all the wildflowers. This earth keeps us going."

6 Abel and Set in N. Scott Momaday's House Made of Dawn (1968) and The Ancient Child (1989); Tayo and Indigo in Leslie Marmon Silko's Ceremony (1977) and Gardens in the Dunes (1999); Ephanie in 
of an identity, a process dependent upon a rediscovered sense of place as well as community (...) is at the center of American Indian fiction."

In Hogan's novel Solar Storms, Angela summarizes the identity quest as a journey in search of wholeness as follows: "I wanted an unbroken line between me and the past. I wanted not to be fragments and pieces left behind by fur traders, soldiers, priests, and schools" (1997: 77). After an odyssey through a series of foster homes, she decides to return to her place of birth, envisioning herself as water flowing back to its source. Set in the 1970s in the Great Lakes region, where scattered members of Cree, Anishinabe, and various other tribes fight against the construction of dams and reservoirs threatening to flood their homelands, the novel describes Angela's "falling into a lake" (1997: 26), the fertile waters of her great-grandmother's storytelling. Later, moving in a canoe up north, and surrounded by water, Angela gradually begins to live

inside water. There was no separation between us. I knew in a moment what water was. It was what had been snow. It had passed through old forests, now gone. It was the sweetness of milk and corn and it had journeyed through human lives. It was blood spilled on the ground. Some of it was the blood of my ancestors. (...) In that moment I understood I was part of the same equation as birds and rain (1997: 78-79).

Stories, the power of words, trigger Angela's thoughts and dreams, which link her to the world of plants and animals in that specific place. This falling into tribal nature-as-culture, where "everything merged and united" (1997: 177), where "the old ones" can be heard "in the songs of wolves" (1997: 176) — an act of interior consciousness by means of which life and identity are called into being within a sacred hoop - enables Angela to envision an alternative reality without borders: "Maybe the roots of dreaming are in the soil of dailiness, or in the heart, or in another place without words, but when they come together and grow, they are like the seeds of hydrogen and the seeds of oxygen that together create ocean, lake, and ice. In this way, the plants and I joined each other" (1997: 171). By joining forces with several other generations of women represented by Agnes, Dora-Rouge, and Bush, assuming responsibility for her younger half-sister, and relocating her self within place-asspace through water tropes, Angela enters and actively shapes tribal history and culture. Angela's reconstruction of identity and her subsequent communal agency, aided by a speaking nature (1997: 118) unleashing floodwaters against the roads of the intruders, align the energy of tribal people with the energy of nature through the

Paula Gunn Allen's The Woman Who Owned the Shadows (1983); the nameless narrator and Jim Loney in James Welch's Winter in the Blood (1974) and The Death of Jim Loney (1979); Fleur's daughter Lulu in Louise Erdrich's Tracks (1988); Willie Begay in Anna Lee Walters's Ghost Singer (1988); Omishto in Linda Hogan's Power (1998); and Jacob Nashoba in Louis Owen's Dark River (1999), to name just a few ailing characters of Native American novels. 
power of words against the interference of white people living in disharmony with the earth.

Solar Storms, then, is a ceremonial representation of an integrated vision of reality opposed to sociocultural definitions of the self and the universe that are based on divisions and lead to the destruction of life on earth. The objective of Hogan's creative and critical writings is to mend the broken covenant between the human and nonhuman worlds, decolonize mental savagism, deconstruct artificial borders through the workings of an inter/transbiotic memory and thereby transform our sense of what it means to inhabit the earth: a sense of place as sense of space characterized by biotic harmony and justice.

This "participatory relationship with the world" (Hogan, 1998:19) as an ongoing process of creation is set up against a system of knowledge based upon exploitation of people and natural resources. Whereas in Solar Storms it is the construction of dams and reservoirs threatening to flood First Nation homelands, in Hogan's novel Mean Spirit Osage Natives struggle for survival against "a world that eats itself and uses up the earth" (1992: 114) in oil-crazed Oklahoma of the 1920s: "a money-hungry world" (1992: 242) set ablaze by the oil industry after oil was found beneath Oklahoma land belonging to Osage people. Both novels, then, delineate how the dispossession of land propelled by a predatory capitalism leads to ecological disaster and spiritual anorexia without however extinguishing Native resilience.

What Hogan calls an ancient way of being is not an exclusive characteristic of the Native American experience as I will demonstrate in the following analysis of Canadian writer Margaret Atwood's novel Surfacing. The narrative delineates the journey of a young woman who returns to northern Quebec, to the remote island of her childhood with her lover and two friends, to investigate the mysterious disappearance of her father. Throughout the journey that lasts about one week, the protagonist is flooded with memories of her childhood and her dead mother - an individual memory (Bergson) imbued with what Ricoeur has termed mémoire des proches set in collective, social memory (Halbwachs) - and realizes that going home means entering not only another place, but other places and times, and accepting the multiple others in one's inner and outer landscape. In the process, memory condenses diverse places, times and species at a present crossroads where the interior and the city, culture and nature, human beings and nonhumans framed by two different systems of knowledge meet in a tension-laden relationship.

Similar to Faulkner, but by means of shorter and less convoluted sentences, Margaret Atwood works the temporal flux, the changes of perspective and the focalization of the characters through the narrative voice to graph the unconscious impulses in her protagonist's mind. In the process, the protagonist's memory reveals diverse forms and practices of violence that human beings inflict upon each other and the environment within a network of power relations characterized by domination and exploitation. To become conscious of the disavowal of a violence that haunts its Verleugnung and to be able to integrate the dislocated and belated traumatic experience as sedimented memory, the protagonist has to 
be more careful about my memories, I have to be sure they're my own and not the memories of other people telling me what I felt, how I acted, what I said: if the events are wrong the feelings I remember about them will be wrong too, I'll start inventing them and there will be no way of correcting it, the ones who could help are gone (1998: 72).

This consciousness-raising, then, requires the deconstruction of "the memories fraudulent as passports" that fill "a faked album", this "paper house" (1998: 149) she has been living in until the beginning of this journey. Grounded in and propelled by social experience, this mnemonic deconstruction establishes a link between the political, cultural and ecological unconscious of Canadian society: the way Canadian (and, in a broader sense, Western) democracy in the 1970s was a hegemonic system based upon the oppression, subalternization and/or exploitation of all the others constituting its inner margin in the name of a ruthless capitalistic economic order and its consumer culture.

Atwood emphasizes the destructive effects of this predatory capitalist order, the disastrous moral cost in hypocrisy, alienation, and destructiveness that Western civilization entails, in the behavior, actions and thoughts of the protagonist's lover and friends; namely, their complete reification. Furthermore, the decolonial attitude of the text lays bare the devastation of the land (fauna, flora, water resources, etc.) by electric companies, lumber business, and tourism in an allegorical way, mirroring human degeneration. At one point in the plot, for example, the protagonist and her three travelling companions come upon a camp of American hunters who had just killed and strung up a heron. This image haunts the protagonist and makes her wonder "what part of them [the hunters] the heron was, that they needed so much to kill it" (1998: 123). I argue that the novel's decolonial attitude problematizes what the environmental philosopher Deane Curtin (2005: 145) has termed "environmental racism": "the connection, in theory and practice, of race and environment so that the oppression of one is connected to, and supported by, the oppression of the other." White Americans hunting game in Canadian woods desecrate the cosmogony of First Nation Peoples. It could be seen as an extreme form of what Val Plumwood (2006: 4) has called "hegemonic centrism": the self-privileging view underlying colonialism, racism, and sexism alike, all of which support each other and have historically been used for the purposes of exploiting nature while reducing nonhuman claims to a shared earth. In the process, we should not forget, as Plumwood (2003: 53) argues, that the western definition of humanity has always depended on the presence of the nonhuman: the uncivilized and the animalistic. The justification for invasion and colonization proceeded and continues to proceed from this racist, anthropomorphic basis - one that negates the independent self of nature and/or projects abjections upon nonhuman elements of the biota as a license to kill. A physical, psychological, 
epistemic and ecological violence resumed in the protagonist's question: "How did we get bad?" (Atwood, 1998: 134). ${ }^{7}$

In order to think this question over, the protagonist distances herself from her travel companions and moves into the wild — with a lake and the woods functioning as locus amoenus - in an attempt at reconstructing her alienated/ fragmented self and way of living and relating to others, human and nonhuman. This immersion into nature - which bears the characteristics of a ritual passage through the limen - constitutes a critique of Western civilization in so far as the protagonist wants to strip herself of all that is artificially induced by the ideological machinery of social normalization. In this sense, she wants to "stop being in the mirror" in order "not to see myself but to see" (1998: 186): to see herself through the other and the other in herself based on mutual respect. This implies that she does not hunt animals with a weapon but "with my hands," since "that will be fair" (1998: 193). This, then, is an inter/ transbiotic identitarian stance expressed as follows: "I lean against a tree, I am a tree leaning" or, "I am not an animal or a tree, I am the thing in which the trees and animals move and grow, I am a place" (1998: 193). The protagonist's relocation of identity - or rather translocation since she seems to move through/with others to arrive at her "place" which is also the place of all the others - substitutes the difference-as-separation that characterizes the relationship between human beings and nonhumans for a diversity-in-relation in which humans and nonhumans coexist in a mutual give-and-take exchange. Her identitarian reconstruction qua translocation, then, carries the message that culture as a human product should not be seen in opposition to nature since human culture resides in and is determined by nature. In other words, our human existence and history is inextricably intertwined with those of other species. What surfaces in Atwood's novel, then, is the destructive savagism of a Western system of knowledge based on consumerism and ruthless exploitation of natural resources. Yet Surfacing disrupts this system through the protagonist's decolonial translocation, her traversing and moving beyond it by means of consciousness-raising, surfacing in a more ancient inter/transbiotic way of thinking and being.

Subalternized subjects negotiate decolonial resistance and survival in this context of physical, epistemic, and ecological violence. In Susan Power's The Grass Dancer Herod, a Native healer, says to Pumpkin, a female dancer:

You have to remember, there's two kinds of Grass dancing, (...). There's the grass dancer who prepares the field for a powwow the old time way, turning the grass over with his feet to flatten it down. Then there's the spiritual dancer, who wants to learn grass secrets by imitating it, moving his body with the wind. I guess a woman should be able to choose her own style (1995: 30).

7 In her essay "Post-Colonial," Atwood asks another pertinent question about Canadians and their collective identity vis-à-vis Native Canadians and immigrants: "Who are we, now, inside the we corral, the we palisade, the we fortress, and who are they?" (2006: 99-100). In this context, see also Northrop Frye (1995) who argued that Canadians are characterized by a "garrison mentality." 
At the end of the novel, Harley, a male dancer, is reminded of the fact that both kinds of grass dancing are equivalent to cultural resilience: “(...) when you move through those old steps, remember that you are dancing a rebellion (...)" (1995: 299). A rebellion against what Leslie Marmon Silko in her novel Almanac of the Dead calls earth "destroyers" (1991: 722), starting with Spanish conquistador and Yaqui butcher Diego de Guzman and continuing in the present with diverse types of militarized violence throughout the Americas: human organ harvesters, U.S.-backed death squads, drug-related serial killings, sexual violence, autocolonialism, the destruction of nature and illegitimate appropriation of native-owned land through multi- and transnational companies aided by local governments, etc. ${ }^{8}$ In addition, a rebellion against what Paula Gunn Allen has described as the "shift from gynecentricegalitarian and ritual-based systems to phallocentric, hierarchical systems" (1992: 40). In the following, I want to focus on this connection between (neo)colonization and patriarchy in Alice Walker's novel The Temple of My Familiar.

A millennium-spanning novel with multiple settings in Africa and the Americas, The Temple of My Familiar presents Lissie, a "womanist" conjure woman who "remembers everything" (1990: 65) of her many lives - a lion, a pygmy, a white man, an African woman who survives the Middle Passage, and an African American professor of history at the University of California, Berkley in the 1980s. ${ }^{9}$ Based on her "dream memories" and on the "faith in herself," Lissie interprets "her own and other people's dreams" to put "together the past in some kind of pattern so that it could be understood in the present" (1990: 120). This "womanist" re-vision of the past from the perspective of a "bisexual" wo-m-an-imal explodes the separative boundaries of patriarchal binary thought and behavior by means of plurality and differentiation, that is, her transfigurations into human and nonhuman others. ${ }^{10}$ With her many selves, Lissie does not only subvert the cause-and-effect linearity of written Western discourse and history and the inherent equations of truth and fact, imagination and falsehood, but she also attacks the materialist patriarchal social structure as a foundational system by means of which language and history function. Against these patriarchal symbols, forms, and practices, which lead to fragmentation, alienation, reification, abjection, violence, and destruction, Walker appropriates Lissie with language based on the ur-matriarchal social structure with characteristics such as (artistic) freedom, (magic) creativity, wholeness, happiness, justice, and peaceful cohabitation. The novel's decolonial attitude, then, resides in an alter-ideological thrust aimed at a rational system of thought and knowledge

8 In The Guardians, by Chicana author Ana Castillo, Miguel asks the following question regarding the transborder violence driven by predatory economic interests: "With so much money involved, how can anyone ever expect this savagery to stop?" (2008: 184).

9 Walker first coined the term in her short story "Coming Apart" (1979) and defined it In Search of Our Mothers' Gardens: Womanist Prose (1983).

10 Hélène Cixous (1994: 41) defines "bisexuality" as "the location within oneself of the presence of both sexes, evident and insistent in different ways according to the individual, the non-exclusion of difference or of a sex, and starting with this 'permission' one gives oneself, the multiplication of the effects of desire's inscription on every part of the body and the other body." 
that has legitimized diverse forms and practices of internal(ized) and external(ized) colonization for centuries. Moreover, Lissie's trickster-like fashion of violating male codes is a decolonial social practice because its ultimate objective is conscientization: the revelation of different lifestyles, diverse ways of thinking, acting and relating to others, the importance of memory, imagination, respect and freedom for individual and collective well-being, the intersectionality of gender, sex, race, class, age, work, education, knowledge, personal and collective interests and values etc. in the (re) construction of identity, as well as in all forms and practices of violence and finally, the necessity to think culture and nature together to stop ecological destruction.

What these women writers write against, then, is a multidimensional devastation that has not stopped since the past: diverse types and practices of violence ravaging the entire biota. An intense and inordinate desire for wealth partly explains why a more participatory worldview does not harmonize with a capitalistic system; a worldview expressed in Laura Esquivel's novel Malinche when Malinalli muses on her relationship with Cortez and on the Spaniard's bestial behavior towards indigenous peoples:

(...) water does not attack water. Maize does not attack maize. Air does not attack air. Land does not attack land. By not recognizing himself in these natural elements, man attacks and destroys them. By attacking himself, man destroys water, maize, the earth and stops pronouncing the name of his gods. The man who does not see that his brother is also the wind, water, maize, the air cannot see god (2008: 177).

Thus, in the novels by inter-American women writers discussed here, resistance qua survival is encoded in the practices of memory, consciousnessraising and writing - practices which together constitute a decolonial aesthetics. Its decolonial nature resides in an intercultural and/or interbiotic system of thought and knowledge that enables us to learn the secrets of the others, human and nonhuman, embrace our denied freedom, and live in peace and harmony on Earth. Gioconda Belli, in O país das mulheres, writes that we need a new type of citizenship based on care, a "Cuidadania," a 'carizenship' educating us to be "Cuidadãos" (2011: 37), citizens qua 'carizens' who take care of "life," "home," and the "emotions of this miserable planet we are destroying," that is, we have to "socialize the practice of care" (2011: 83). This socialization of care produces happiness, "per capita" instead of "the growth of the gross national product as axis of development" (2011: 85). The ultimate objective of this governmental project run by women in Belli's novel is to change the world in order to safe it: "We want an other world, we want to avoid that humanity completes the cycle of its existence by destroying itself" (2011; 182). A world, the narratives of Belli, Atwood, Hogan, Silko, Potiguara, Esquivel, Kincaid, Morrison, and Walker suggest, that is based on respect for and tolerance of what Liane Schneider (2008: 192) calls "the implicit recognition of plurality" of our human 
identities and identifications. This in itself is a remarkable decolonial attitude. Even more striking in this textual attitude is the fact that the select texts analyzed in this essay expand this "recognition of plurality" to the nonhuman worlds of plants, trees, and animals. This inter/ transbiotic vision decolonizes our anthropomorphic position into a more equalitarian relationship with other species on Earth.

\section{Referências}

ALARCÓN, Francisco. (1992). "Reclaiming Ourselves, Reclaiming America." In: GONZÁLEZ, Ray (org.). Without Discovery: A Native Response to Columbus. Seattle, WA: Broken Moon Press. p. 29-38.

ALLEN, Paula Gunn. (1992). The Sacred Hoop. Recovering the Feminine in American Indian Traditions. Boston, Beacon Press.

ALLENDE, Isabel. (2011). Island Beneath the Sea. Trad. Margaret Sayers Peden. New York: Harper Perennial.

AMIN, Samir. (2000). Capitalism in the Age of Globalism. London/ New York: Zed Books.

ARTEAGA, Alfred. (1994). “An Other Tongue.” In: ARTEAGA, Alfred (org.). An Other Tongue. Nation and Ethnicity in the Linguistic Borderlands. Durham/London: Duke UP. p. 9-33.

ATWOOD, Margaret. (1998). Surfacing. New York: Anchor.

ATWOOD, Margaret. (2006). “Post-Colonial.” In: ATWOOD, Margaret. The Tent. New York: Doubleday.

BELLI, Gioconda. (2011). O país das mulheres. Trad. Ana Resende. Campinas: Verus.

BENÍTEZ-ROJO, Antonio. (2005). "Sugar and the Environment in Cuba." In: DELOUGHREY, Elizabeth M.; GOSSON, Renée K.; HANDLEY, George B. (orgs.). Caribbean Literature and the Environment. Between NatureandCulture. Charlottesville/ London : University of Virginia Press. p.33-50.

BERGSON, Henri. (2006). Matéria e Memória. Ensaio sobre a relação do corpo com o espírito. Trad. Paulo Neves. São Paulo: Martins Fontes.

BLOCH, Ernst. (1985). Das Prinzip Hoffnung. Frankfurt: Suhrkamp. 
CASTILLO, Ana. (2008). The Guardians. New York: Random House.

CHIEF Joseph (1971). In: MCLUHAN, T.C (org.). Touch the Earth: A Self-Portrait of Indian Existence. New York: Simon and Schuster. p. 54.

CIXOUS, Hélène (1994). “The Newly Born Woman.” In: SELLERS, Susan (org.). The Hélène Cixous Reader. London: Routledge. p. 35-46.

CROW DOG, Mary (with Richard Erdoes). (1990). Lakota Woman. New York: Harper Perennial.

CURTIN, Deane W. (2005). Environmental Ethics for a Postcolonial World. Lanham: Rowman \& Littlefield.

ELIA, Nada. (2001). Trances, Dances, and Vociferations: Agency and Resistance in Africana Women's Narratives. New York: Garland.

ESQUIVEL, Laura. (2008). Malinche. México D.F.: Atria.

FANON, Frantz. (1967). Black Skin, White Masks. Trans. Charles L. Markmann. New York: Grove Press.

FAULKNER, William. (1977). “The Bear.” In: COWLEY, Malcom (org.). The Portable Faulkner. New York: Penguin. p. 197-320.

FRYE, Northrop. (1995). The Bush Garden: Essays on the Canadian Imagination. Toronto: Anansi.

HALBWACHS, Maurice. (1968). La mémoire collective. Paris: Presses Universitaires de France.

HOGAN, Linda. (1995). Dwellings: A Spiritual History of the Living World. New York: W.W. Norton \& Company.

HOGAN, Linda. (1998). "First People." In: HOGAN, Linda; METZGER, Deena; PETERSON, Brenda (orgs.). Intimate Nature: The Bond between Women and Animals. New York: The Ballantine Publishing Group. p. 6-19.

HOGAN, Linda. (1998). “Introduction.” In: HOGAN, Linda; METZGER, Deena; PETERSON, Brenda (orgs.). Intimate Nature: The Bond between Women and Animals. New York: The Ballantine Publishing Group. p. xi-xvi.

HOGAN, Linda. (1992). Mean Spirit. New York: Ballentine. 
HOGAN, Linda. (1997). Solar Storms. New York: Scribner.

KINCAID, Jamaica. (1989). A Small Place. New York: Plume.

LUGONES, María (2008). “Colonialidad y Género”. Tabula Rasa, n.9: p.73-101, jul-dez.

MAREÁTEGUI, José Carlos. (2009). Siete ensayos de interpretación de la realidad peruana. Buenos Aires: Capital Intelectual.

MORRISON, Toni. (2008). A Mercy. New York: Alfred A. Knopf.

MORRISON, Toni. (1989). Beloved. New York: Signet.

MORRISON, Toni. (1998b). “Home.” In: LUBIANO, Wahneema (org.). The House That Race Built. New York: Vintage. p. 3-12.

MORRISON, Toni. (1998a). Paradise. New York: Alfred A. Knopf.

MORRISON, Toni. (1983). Tar Baby. New York: Signet.

MORRISON, Toni. (1990). "Unspeakable Things Unspoken: The Afro-American Presence in American Literature.” In: BLOOM, Harold. (org.). Toni Morrison. New York: Chelsea House Publishers. p. 201-30.

OWENS, Louis. (1992). Other Destinies: Understanding the American Indian Novel. Norman: University of Oklahoma Press.

PLUMWOOD, Val. (2003). "Decolonizing Relationships with Nature.” In: ADAMS, William H.; MULLIGAN, Martin (orgs.). Decolonizing Nature: Strategies for Conservation in a Post-Colonial Era. London: Earthscan. p. 51-78.

PLUMWOOD, Val. (2006). Environmental Culture: The Ecological Crisis of Reason. London: Routledge.

POTIGUARA, Eliane. (2019). Metade Cara, Metade Máscara. Rio de Janeiro: Crumin.

POWER, Susan. (1995). The Grass Dancer. New York: Picador.

QUIJANO, Anibal. (1998). "La colonialidad del poder y la experiencia cultural latinoamericana.” In: BRICEÑO-LEÓN, Roberto; SONNTAG, Heinz R. (orgs.). Pueblo, época y desarrollo: la sociología de América Latina. Caracas: Nueva Sociedad. p. 139155 .

RAMONET, Ignacio. (2002). Géopolitique du chaos. Paris: Gallimard. 
RICOEUR, Paul. (2000). La mémoire, l'histoire, l'oubli. Paris: Seuil.

SCHNEIDER, Liane. (2008). Escritoras Indígenas e a Literatura Contemporânea dos EUA. João Pessoa: Ideia.

SILKO, Leslie M. (1992). Almanac of the Dead. New York: Penguin.

SILKO, Leslie M. (1977). Ceremony. New York: Penguin.

SILKO, Leslie M. (1997). Yellow Woman and the Beauty of the Spirit. Essays on Native American Life Today. New York: Touchstone.

WALKER, Alice. (1990). The Temple of My Familiar. New York: Penguin.

Recebido em 30/05/2020.

Aceito em 19/06/2020. 